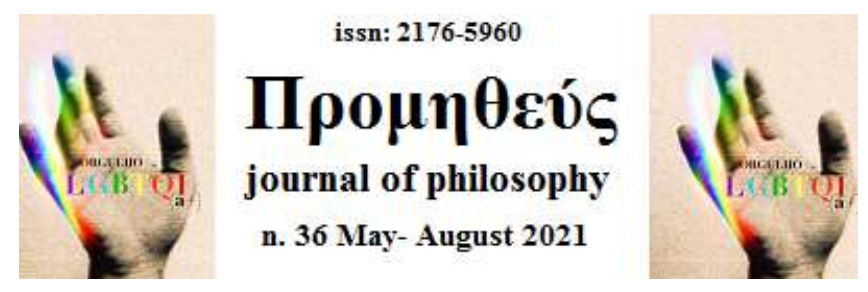

\title{
REFLEXÕES ÉTICO-MUSICAIS EM DIÓGENES DA BABILÔNIA
}

\section{Marcos Vinicios Pereira de Almeida ${ }^{1}$}

Resumo: Neste trabalho pretendemos fazer uma abordagem das implicações éticomusicais no pensamento do filósofo estoico Diógenes da Babilônia. O objetivo é analisar o pensamento de Diógenes a partir dos fragmentos lacunosos que chegaram até nós, mais precisamente através do De Musica do Filodemo de Gadara e do trabalho da Helen Woodward, e entender seu contexto histórico-filosófico. Portanto, nosso curso passa por uma contextualização de Diógenes e da sua abordagem estoica da música.

Palavras-chaves: Ética. Música. Estoicismo.

Abstract: In this work we intend to approach the ethical-musical implications in the thought of the stoic philosopher Diogenes of Babylon. The purpose is to analyze Diogenes' thinking based on the lacunae fragments that have come down to us, more precisely the De Musica by Philodemus of Gadara and also Helen Woodward's work, and to understand his historical-philosophical context. Therefore, our course goes through a contextualization of Diogenes and his stoic approach to music

Keywords: Ethic. Music. Stoicism.

\footnotetext{
${ }^{1}$ Bacharel em filosofia pela Universidade Federal de Goiás e mestrando no PPG de Filosofia da Universidade Federal de Goiás.
} 


\section{Introdução}

Este trabalho tem por objetivo analisar as reflexões ético-musicais de Diógenes da Babilônia (230 a.C.-150/140 a.C.), em especial sua visão estoica da música e suas implicações éticas. Diógenes da Babilônia foi um filósofo estoico que viveu em Atenas, comandou a escola estoica na mesma cidade e foi um dos filósofos, junto com o acadêmico Carnéades, enviados a Roma em 155 a.C.. Diógenes escreveu diversas obras, como Sobre Atenas e Sobre a Música, do qual nos chegaram apenas os fragmentos por meio do De Musica do epicurista Filodemo de Gádara. O texto de Filodemo foi descoberto em forma de papiro na Villa dei Papiri em Herculano. Por meio desse texto danificado e lacunoso de Filodemo é que chegou até nós os fragmentos do Sobre a Música de Diógenes.

O De Musica de Filodemo foi reconstruído e organizado pelo professor Daniel Delattre em seu PhD, mais precisamente o livro IV, em que Filodemo rebate as teses de Diógenes sobre a música. Além disso, é também no livro IV que encontramos os fragmentos de Diógenes. Vamos nos concentrar aqui no pensamento de Filodemo apenas à medida que ele nos fornece o conteúdo necessário para compreendermos a abordagem de Diógenes a respeito da música e de suas implicações éticas.

Antes do século V a.C., a música era basicamente um mero detalhe por trás da poética-religiosa das Musas. Só depois, no século IV a.C., que a música começa a ganhar contornos de "independência". Esse tipo de mudança na música foi observado com preocupação tanto por Platão quanto por Diógenes. Naquele período, no final do século V a.C. em diante, os flautistas e músicos já se apresentavam com seus instrumentos independentemente do texto poético-religioso. Plutarco, em Sobre a Música, descreveu essas mudanças fundamentais na composição do aulos e também da lira, no sentido de que essas mudanças transformaram a composição musical de simples para mais complexa:

De modo semelhante também Melanípides, o compositor de melodias, que veio depois, não permaneceu fiel à música anterior a ele, nem Filóxeno nem Timóteo. Esse, de fato, sendo a lira, antes, até a época de Terpandro de Antissa, de sete notas, dividiu-as em numerosas notas. Mas também a aulética passou de uma música mais simples para outra mais complexa (PLUTARCO, Sobre a Música, 1141c). 
É importante notar que essa mudança na música observada por Plutarco foi também motivo de preocupação de filósofos anteriores. Esse é um ponto comum entre Plutarco, Platão e Diógenes, isto é, o problema daquilo que os modernos chamam de "nova música", que ocorreu entre o século V e IV a.C., como mostra Plutarco em seu livro Sobre a Música.

Para Platão, e também para Diógenes, existe uma conexão entre musiké e éthos. Ou seja, a harmonia pode afetar o comportamento das pessoas, seu carácter e, portanto, sua forma de agir. Na República podemos observar claramente a discussão a respeito da técnica musical atrelada ao comportamento: "E não será essa a razão, Gláuco, da educação na música e na poesia e ser sumamente importante? Primeiramente porque ritmo e harmonia permeiam o interior da alma mais do que qualquer outra coisa [...] (399a-402a)". Essa tradição que identifica uma relação entre harmonia e éthos já não era nova no contexto de Platão, pois é facilmente encontrada na figura religiosa de Orfeu, que, ao tocar lira, fazia até objetos inanimados se moverem. Outro filósofo importante dessa tradição músico-pedagógica é Damon, que viveu por volta de 500 a.C. Segundo Lia Tomás (2007), Damon foi o primeiro a olhar as mudanças musicais como nocivas às pessoas, tendo em vista que ele entende que a harmonia musical provoca uma movimentação profunda nos espíritos e, também, pode causar danos sociais.

No Areopagítico, nome pelo qual ficou conhecido este discurso, Damon retoma a teoria da ética musical proveniente de antigas crenças sobre a música como formadora da alma [...] Damon fundamenta sua teoria na premissa de que as diversas harmonias provocam no espírito um movimento correspondente. Cada uma das harmonias "imitando" um determinado modo de ser provoca uma direta e recíproca correspondência com a alma através do movimento. $\mathrm{O}$ ponto chave desta correspondência assenta-se no fato de que durante o século V a.C., os modos musicais eram identificados com os ethoi, ou seja, com diferentes caracteres ou estados anímicos. Consequentemente, cada modo produzia um efeito muito específico sobre o espírito, podendo ainda imitar os costumes de seu país de origem, bem como o tipo de regime existente (TOMÁS, 2007, p. 149).

Damon está inserido dentro de uma tradição pitagórica de música, como assinala Fubini (2005). Além disso, é importante observar que, em Damon, existe uma ênfase maior no aspecto moral da música, mais do que em seu aspecto matemático, que está implícito em suas concepções pitagóricas de música. Pelo menos é o que podemos dizer a respeito de Damon, cujo trabalho escrito não chegou até nós, apenas relatos e anedotas via Platão, Aristóteles, Filodemo e Aristides Quintiliano. Por outro lado, podemos ver, 
pelo o material que temos hoje, que Damon foi uma influência importante para os filósofos que se preocuparam com a mudança do cenário musical grego e mediterrâneo do século V a.C., que viam essas mudanças como negativas para os costumes da época. Fubini (2005), por exemplo, sugere que Damon foi uma forte influência para Platão pensar em uma legislação para a música, tendo em vista que, se a música - para Damon - induz à virtude, ela também pode induzir ao erro, porque uma harmonia imita um determinado modelo de $\operatorname{ser}^{2}$. É nesse sentido que surge uma urgência para se pensar na educação musical naquele período e, de certo modo, pensar em uma legislação para ordenar e orientar a educação musical ${ }^{3}$.

É importante ter em mente esse contexto filosófico e musical da antiguidade para compreender o pensamento de Diógenes da Babilônia a respeito da música e de suas implicações éticas. Já que Diógenes está em diálogo com esse contexto e com esses autores, a saber, o contexto do século V/IV a.C. e os autores que escreveram a respeito da mudança musical dessa época - Platão, por exemplo - são os interlocutores de Diógenes. De acordo com Thomas J. Mathiesen, em uma passagem breve de um verbete da The Routledge Companion to Philosophy and Music, e na rasteira da obra de Filodemo, ele define a contribuição da filosofia da música de Diógenes:

Filósofos epicuristas e céticos geralmente rejeitavam a ideia de que a música representava qualquer coisa além de si mesma ou detinha qualquer poder especial para afetar o caráter humano (éthos). No Livro IV de seu tratado fragmentário De Musica, o epicurista Filodemo (110 a.C-35 a.C.) resume e refuta sistematicamente cada argumento do estoico Diógenes da Babilônia (240 a.C.-150 a.C.), que representa uma síntese do pitagorismo, pontos de vista platônicos e aristotélicos (MATHIESEN, 2011, p. 261, tradução nossa).

Mathiesen está certo por um lado, mas o pensamento de Diógenes não se reduz à uma síntese pitagórica, platônica e aristotélica. É certo que Diógenes não concordava com os epicuristas, pois, ele não rejeitava o carácter ético e metafísico da música. Isso faz dele um platônico? Não. Diógenes com certeza concordava com Pitágoras, Damon, Platão e Aristóteles, no sentido que a música afeta o éthos de um sujeito. A diferença é

\footnotetext{
2“Esse conceito de imitação - típicos dos teóricos do período tardio - se justifica em virtude do princípio de que a tensão das cordas da lira encontra sua correspondência na tensão da alma" (FUBINI, 2005, p. 61, tradução nossa).

${ }^{3}$ Platão, na República, declarou que os únicos modos aceitos são o Dório e o Frígio, porque são os únicos que provocam a bravura na alma: "As jônicas e as lídias, que são tidas como relaxadas. Tu as utilizarias em alguma oportunidade para transformar indivíduos em guerreiros? Jamais. E com isso tudo que sobrou são as modalidades dórias e frígias" (PLATÃO, A República, 399a).
} 
que Diógenes constrói sua visão da música, não baseado em uma psicológica platônica, mas em uma psicologia e metafísica estoica. Portanto, é a partir desse ponto e dessas diferenças que vamos compreender as reflexões ético-musicais de Diógenes, o estoico.

\section{1. Ética e psicologia estoica}

Como mencionamos antes, Diógenes concorda com Platão quanto à importância do impacto da música no éthos. A diferença entre os dois filósofos está na ética e na psicologia estoica. Para entendermos melhor a abordagem racional da música de Diógenes, é importante compreendermos como ela se encaixa na teoria das paixões estoica. A psicologia estoica aqui consiste em uma teoria das paixões e também uma teoria da ação, visto que as emoções fundamentam determinadas ações éticas.

Dito isso, Diógenes concorda com a definição de telos da teoria ética estoica, isto é, que o fim de uma ação virtuosa é viver em concordância com a natureza ${ }^{4}$. Logo depois, Diógenes apenas acentuou o aspecto seletivo da teleologia estoica: "Diógenes define expressamente como fim supremo agir racionalmente na escolha do que é conforme a natureza" (D.L. VII. 88). Porém, quais as características da psicologia estoica? Segundo Crisipo ${ }^{5}$, o que constitui a psicologia estoica é que as paixões são frutos de um julgamento ${ }^{6}$. No estoicismo as paixões possuem um carácter cognitivo, a saber, a nossa razão é una, e a paixão entra na alma na medida em que aceitamos através do assentimento (sunkatathesis) ${ }^{7}$. Ou seja: a psicologia estoica não diz que nossa razão é trocada, mas sim corrompida por um julgamento ruim. Portanto, em vez de ser uma psicologia dualista de gosto platônico, com uma divisão da alma entre racional e irracional, trata-se, na verdade, de uma ideia de mal uso da razão. Ademais, parece que Diógenes não discorda da psicologia estoica ortodoxa, em que a alma é una, em que a paixão é fruto de um processo cognitivo. Na Col. 14 do texto de Filodemo, tem um fragmento de Diógenes que mostra essa concordância com a teoria da ação estoica:

\footnotetext{
4"Por isso Zenão foi o primeiro, em sua obra Da Natureza do Homem, a definir o fim supremo como viver de acordo com a natureza, ou seja, viver segundo a excelência, porque a excelência é o fim para o qual a natureza nos guia [...] No livro de sua obra Dos Fins, Crisipo afirma também que viver segundo a excelência coincide com viver de acordo com a experiência dos fatos da natureza, e que nossas naturezas individuais são parte da natureza universal" (D.L. VII. 87).

${ }^{5}$ Crisipo de Solos foi um filósofo estoico grego responsável por sistematizar o pensamento estoico.

“'Os estoicos sustentam que as paixões são juízos, como afirma Crisipo na obra Das paixões” (D.L. VII. 111).

7“'Ora, como nos seres racionais todo impulso implica em um assentimento da parte diretora da alma a uma impressão racional, quer dizer, inclui um juízo, bastará, para dominar suas paixões, dominar seus juízos" (HUSSON, 2013, p. 141).
} 
“Além disso, uma educação[...] para a virtude [...] gera certos impulsos; e, uma vez que as ações morais surgem por meio de uma escolha deliberada, para apreender o assunto em linhas gerais, certas afeições acompanhadas de capacidade tornam-se intenções" (Filodemo, De Musica, Col. 14, tradução nossa). Em seguida, na coluna 89, em uma passagem que Filodemo responde Diógenes:

[Diógenes] diferencia porque ele concederá isso, mesmo que afirme que música inspira impulsos, e que as intenções são certas afeições (pathê) acompanhadas de inteligências, que [às vezes] é [a mesma coisa]. Por isso a origem de adquirir estas intenções e força são afeições - audácia provoca à coragem, vergonha e reserva à temperança, e assim por diante (FILODEMO, De Musica, Col. 89, 27, tradução nossa).

De acordo com essa passagem de Filodemo, percebemos que Diógenes não diferencia afeições de virtude, assim como o valor ético também significa conhecimento perceptivo. Ele está de acordo com a psicologia estoica ortodoxa, e em desacordo com o uma psicologia platônica que, grosso modo, distingue a alma em uma parte racional e outra irracional. Portanto, mesmo que Diógenes tenha aceitado a visão de seus antecessores (Damon, Platão) a respeito do papel da música como disciplina propedêutica, isso não significa que ele tenha aceitado por inteiro o arcabouço filosófico desses autores.

Desse modo, surgem alguns problemas que devem ser abordados aqui, pois a epistemologia estoica diz que a paixão (pathê), por exemplo, o medo, é fruto de um assentimento (synkatathesis) à proposição "algo ruim está acontecendo e preciso evitálo" (DINUCCI, 2019, p. 320). Ou seja, na psicologia estoica um juízo disjuntivo que contém um conteúdo racional deve ser formado em uma proposição em letra. Segundo Woodward (2009), a psicologia estoica parece entrar em conflito com o conteúdo musical, pois; se a música tem um valor psicológico para o estoicismo de Diógenes, então ela é racional. E se a música é racional, então ela esbarra em outro problema: a música tem que ter um conteúdo proposicional em palavras. No entanto, se a palavra está envolvida, não seria necessário explicar o efeito da música sob o ouvinte, porque se a palavra e só ela pode causar assentimento (synkatathesis), então uma melodia não faria efeito algum, assim a música parece não ter um valor inerente a si mesma (WOODWARD, 2009, p. 19). 
Cleantes de Assos, filósofo estoico que antecedeu Diógenes, concorda que a música tem um efeito valorativo sobre às pessoas, sobretudo quando o pensamento acompanha uma melodia estruturalmente organizada com métrica e ritmo. Dellatre (2007) e Woodward (2009), sugerem que Diógenes concordava com Cleantes, a saber, que a música forma um fenômeno, ou um tipo de linguagem, que nos aproxima do divino, do télos da vida virtuosa, que é viver de acordo com a natureza ${ }^{8}$. É na rasteira de Cleantes que Diógenes vai buscar um estatuto científico para a música, embora ela [a música] possa não ter um conteúdo proposicional em palavras, Diógenes parece explorar outro caminho dentro da filosofia estoica para explicar essa linguagem específica da música que nos afeta e provoca ações.

[...] a música também permite a criança adquirir um bom ouvido e, em geral, uma agudeza de percepção sob a influência do ritmo, visto que ela [a música] possui certas virtudes naturais inatas; pois, ela diz o que é mais forte em todas as coisas, assim também o que é adequado (kathêkon), o que é semelhante é assimilado mais facilmente e levado para alguém a partir de suas sensibilidades, e como resultado nossos prazeres e nossos afetos e em geral nossas sensações serão mais fortes por conta da música [...] (FILODEMO, De Musica, Col. 18, tradução nossa).

Nessa coluna, que é uma das passagens fragmentárias de Diógenes, vemos ele dizer que a música sem palavras provoca um efeito na alma das pessoas desde o nascimento. Primeiro, é importante dizer que "virtude" é entendida aqui no sentido estoico, a saber, o estoicismo entende que bem e virtude são a mesma coisa, existe uma identidade entre virtude, bom e felicidades (eudaimonia $)^{9}$. É uma herança intelectualista socrática que diferencia a concepção estoica de virtude da concepção aristotélica ${ }^{10}$. Além disso, a ética estoica é naturalista, como foi mostrado nos parágrafos anteriores quando explicamos a teleologia estoica. Pois bem, um outro conceito estoico que fora importante para Diógenes dar um tratamento científico para a música, é o conceito estoico de oikeiôsis, do qual vamos discorrer um pouco para entender como esse

\footnotetext{
${ }^{8}$ Essa sugestão faz muito sentido, tendo em vista que Filodemo responde e cita Cleantes no De Musica, isso parece sugerir que Diógenes está de acordo com a visão do seu companheiro de escola: “[...] que os padrões poéticos e musicais são melhores que o discurso filosófico e seja capaz de expressar divina e humana o que importa adequadamente [...] pois, enquanto métrica, melodias e ritmos chegam mais perto da verdade na contemplação do divino" (FILODEMO, De Musica, Col. 142, tradução nossa).

${ }^{9}$ (D.L. VII. 89, 90).

${ }^{10}$ "Na verdade, uma vez que os estoicos não dividem a alma humana em uma parte racional e uma ou várias partes irracionais, eles não precisam distinguir, ao contrário de Aristóteles, virtudes intelectuais e virtudes morais, e definem a virtude como uma e mesmo única ciência - ou seja, como um sistema de representações compreensivas, certas, firmes e inegáveis" (BÉNATOUÏL, 2013, p. 125).
} 
conceito pode nos ajudar a entender a abordagem musical na filosofia de Diógenes da Babilônia.

\section{Oikeiôsis}

Woodward (2009) sugere que para Diógenes ${ }^{11}$, assim como para Platão ${ }^{12}$, a música é um presente dos Deuses e cumpre uma função divina, porque Diógenes faz uma associação etimológica da música com as Musas. Segundo Diógenes, a musa Erato é um exemplo da relação privilegiada entre música e amor virtuoso: "Prova adequada do fato de que a melodia contribui para a gestão do amor erótico também é fornecido por uma das Musas, na verdade, sendo chamada de Erato" (FILODEMO, De Musica, Col. 43, tradução nossa). Ademais, Woodward (2009) analisa que no pensamento estoico os Deuses são providenciais. Poder-se-ia dizer que os estoicos têm uma concepção de divindade imanente ${ }^{13}$, e com isso pensar que aquilo que é dado naturalmente pelos Deuses aos humanos é bom, na medida em que eles fazem um uso adequado e aperfeiçoado desses benefícios divinos. Enfim, é importante dizer isso porque Diógenes faz uma associação entre ação virtuosa e os intervalos corretos na escala musical, na passagem que foi anteriormente citada ele parece sugerir algo desse tipo “[...] uma agudeza de percepção sob a influência do ritmo, visto que ela [a música] possui certas virtudes naturais inatas" (FILODEMO, De Musica, Col. 18, tradução nossa). Essa analogia entre virtude (areté) e escala musical é feita por Long (1996) e Woodward (2009), tendo em vista que nessa passagem Diógenes faz uma associação da música com a natureza, que é o próprio Zeus.

Assim, na passagem supracitada, na coluna 18, Diógenes usa as palavras "semelhante" e "assimilação" para mostrar a relação mais íntima e fundamental dos seres. Alguns autores, como Woodward (2009), sugerem que essa passagem se refere ao conceito estoico de oikeiôsis. A oikeiôsis significa em grego, de forma geral, “apropriação", "familiaridade", "afinidade", e no sentido técnico estoico significa àquilo

\footnotetext{
${ }^{11}$ Filodemo relata que Diógenes escreveu sobre a associação entre música e a devoção aos Deuses: "Era uma música séria regulamentada por leis, diz ele, que foi criada antes de tudo para honrar o divino, e então educar os homens que nasceram livres". (FILODEMO, De Musica, Col. 38, tradução nossa).

${ }^{12}$ PLAT ÃO, República, IV, 424e.

13"Deus é uma substância única, quer se chame mente, ou destino, ou Zeus, mas é designado ainda por muitos outros nomes. No princípio, Deus estava só em seu ser, e transformava toda a substância em sua volta por meio do ar em água; e como no sêmen está o germe, da mesma forma aquilo que é a razão seminal do cosmos permanece como Criador no úmido, de tal maneira que a matéria passa a ter por sua obra a faculdade de continuar a gerar" (D.L. VII. 135,136).
} 
que podemos considerar a relação mais fundamental de todos os seres com o mundo, uma relação de apropriação, onde um bebê, por exemplo, não deseja sua própria destruição, mas busca autopreservar-se ${ }^{14}$. Assim, Diógenes parece sugerir que existe uma assimilação natural entre música e virtude. Essa sugestão de Diógenes faz muito sentido dentro do sistema estoico. Pois a oikeiôsis consiste na fase de apropriação em que todos os seres vivos buscam o natural, a autopreservação, o suficiente, e, portanto, a virtude. A música parece figurar como a causa pela qual a pessoa educada para a virtude a reconhece naturalmente, conforme seu carácter racional. De acordo com Woodward (2009):

Assim (Col. 18), Diógenes talvez esteja sugerindo que a alma instintivamente reconhece e busca ativamente a bondade ou virtude inerente à música, e porque a virtude está "naturalmente arraigada nos seres humanos", então esta virtude na música se atribui ainda mais facilmente por afiliação (oikeiôsis) natural. De acordo com os estoicos, a natureza inicialmente dá aos humanos o suficiente para se orientar para o bem e a virtude, por meio de seleção racional dos indiferentes. Portanto, mesmo uma pessoa não educada para a música pode reconhecer que ela tem uma base racional, porque de acordo com os estoicos, a natureza tudo o faz (WOODWARD, 2009, 32, tradução nossa).

A oikeiôsis na teoria estoica é a potencialidade das virtudes nos seres humanos desde o nascimento, na medida em que, antes da "idade da razão", o ser humano começa a distinguir os males dos bens, e os indiferentes (adiaphora) ${ }^{15}$. Poder-se-ia dizer que Diógenes encontrou um campo fértil para a música sem perder seu compromisso com a ortodoxia estoica. Pois, segundo o que Woodward (2009, p. 34) sugere, Diógenes encontrou no conceito de oikeiôsis um lugar para um tipo de música em que seu reconhecimento como algo virtuoso vem por assimilação ${ }^{16}$.

O reconhecimento da música como algo virtuoso por assimilação pode ser entendido como uma resposta de Diógenes ao tratamento cognitivo da música, a saber, que a música é um tipo de linguagem compreensível para os seres humanos no processo cognitivo, mesmo que certa música não seja descrita ou constituída por palavras.

\footnotetext{
14،"Segundo os estoicos, os animais recebem da natureza uma apropriação ou afinidade (oikeiôsis) em relação a si mesmos, quer dizer, sentem o que são suas partes e as funções delas, e são por elas afetados positivamente, embora seu "impulso primeiro" seja de conservar a si mesmos, o que os conduz a distinguir em seu ambiente as "coisas naturais", que os conservam, e as coisas "contra natureza", que os prejudicam” (BÉNATOUÏL, 2013, p. 119).

${ }^{15}$ Os "indiferentes" (adiaphora) na filosofia estoica é tudo aquilo que não é bom e nem mal.

${ }^{16}$ (FILODEMO, De Música, Col. 18).
} 
Nussbaum (2001) explica o que é esse estatuto de linguagem a que nos referimos ao falar da música:

[...] a linguagem é um meio de representação. Quando expressamos o conteúdo de uma emoção em palavras, já estamos, em muitos casos, realizando uma tradução de pensamentos [...] Em segundo lugar, a música é outra forma de representação simbólica. Portanto, não parece óbvio que pensamos que há um problema maior em expressar o conteúdo de uma emoção musicalmente do que em expressá-la linguisticamente (NUSSBAUM, 2001, p. 234, tradução nossa).

Logo, quando uma pessoa escuta uma música em outro idioma, mesmo que ela não compreenda aquele idioma, ela possivelmente vai ser afetada pela melodia ou pelo ritmo da música. Um bebê que ouve uma canção de ninar nos braços da mãe consegue acalmar-se sem mesmo ter uma compreensão técnica do que significam aquelas palavras. Assim, parece que Diógenes entende que é possível que a linguagem musical afete o éthos de um sujeito sem necessariamente ocorrer uma expressão verbal, e a falta de compreensão técnica da música não significa, também, uma falta de compreensão da música e de seus efeitos. Portanto, Diógenes entende que a música possui uma linguagem própria.

\section{Percepção}

Na coluna 34, Filodemo diz que Diógenes faz uma distinção entre dois tipos de percepção. Uma percepção natural, p. ex., que reconhece o frio, o quente. E uma percepção consciente, que percebe que uma coisa está em harmonia com a outra ${ }^{17}$. Diógenes entende que para saber "o que está em harmonia e o que não está"18, é necessária uma percepção consciente que implica um conhecimento, isso sugere que Diógenes fala de uma percepção adquirida por meio da educação, assim como boas escolhas na ética estoica. Como mostramos nos parágrafos anteriores, o lema "viver de acordo com a natureza" dos estoicos é estendido por Diógenes que enfatiza o carácter seletivo dessa máxima. Ademais, essa distinção entre dois tipos sensoriais não entra em conflito com o conceito de oikeiôsis que mencionamos anteriormente. Pois a alma é instintivamente atraída pela virtude inerente à música, simplesmente pelo carácter correto e harmonioso da mesma, mesmo que a criança, p. ex., não conheça as

\footnotetext{
${ }^{17}$ Mas ele [Diógenes] concordou que [entre os sentidos] algumas coisas precisam da percepção natural, as outras de uma percepção consciente; coisas quentes e frias [precisam] da percepção natural, o que está em harmonia e o que não está [precisa] de uma percepção consciente (FILODEMO, De Musica, Col. 34, tradução nossa).

${ }^{18}$ Idem.
} 
características técnicas que produzem uma melodia harmoniosa; posteriormente, ao alcançar a "maioridade", a criança chega à idade adequada para que sua percepção natural seja educada na boa música, na medida em que características naturais são aperfeiçoadas (WOODWARD, 2009, 39).

Por conseguinte, Diógenes está preocupado em dar um tratamento científico e racional para a música, como foi dito antes. Diferentemente de Filodemo, Diógenes não reduz a música a mero divertimento irracional. Em outra passagem fragmentária, Diógenes disserta mais sobre isso: "[...] a música é boa para a inteligência porque contém definições, divisões e demonstrações" (FILODEMO, De Musica, Col. 38, tradução nossa). Ou seja, os músicos estão preocupados com definições, com a composição, com intervalos, ritmo, e assim por diante. De acordo com Diógenes, apenas uma pessoa treinada poderia reconhecer essas qualidades musicais, e isso denota que a música não é um fenômeno irracional, mas algo que envolve racionalidade e precisão. Segundo Long (1996), para Diógenes, a definição e o limite parecem sugerir uma semelhança com a prática virtuosa, a saber, a harmonia surge de acordo com as notas de uma música em sintonia; as notas devem ser consoantes umas com as outras a fim de formar uma harmonia perfeita e natural ${ }^{19}$.

Além do mais, como apontado por Woodward (2009), é nesse sentido que a música e seu núcleo são definidos pelo limite, a saber, a definição de viver em harmonia com a natureza é excelente nesse contexto ${ }^{20}$, pois, a ideia matemática de proporção musical (de gosto pitagórico) parece estar presente no pensamento musical de Diógenes $^{21}$. Ainda que os estoicos anteriores tenham tratado das definições ${ }^{22}$, não era exatamente sobre as definições ou escalas musicais, como o dório e o frígio. Por outro lado, Helen Woodward (2009) sugere que definições, divisões e demonstrações, são um vocabulário presente em Aristóxenes, e que Diógenes tenha tido contato com a teoria musical do filósofo peripatético nesse período, embora essa sugestão não seja pautada em alguma citação de Diógenes além do vocabulário usado pelo filósofo. Mas é

\footnotetext{
19،“O mundo estoico é uma estrutura sistemática em que tudo se encaixa de acordo com um plano divino e racional. Ao propor "harmonia" como um nome para esta estrutura e "harmoniosamente" como o modo de vida apropriado, os estoicos pretendiam ligar sua filosofia à arte que vem primeiro à mente como o repositório de consonância e concordância - música" (LONG, 1996, p. 203). ${ }^{20}$ (D.L. VII. 88).

${ }^{21} \mathrm{~A}$ Coluna 42 do De Musica parece indicar uma influência pitagórica, mas o fragmento está cheio de lacunas e difícil de compreensão, como ressalta Helen Woodward (2009).

${ }^{22}$ Crisipo escreveu a respeito desse tema em um livro intitulado "As Definições" (D.L. VII. 45).
} 
possível, visto que, em outro contexto, Filodemo cita Aristóxenes em seu De Musica. Enfim, Diógenes possivelmente está ciente de que a música - e aqui ele concorda com Platão - pode ser ensinada às pessoas assim como a virtude, considerando que existe uma divisão sensorial entre uma percepção natural e uma percepção consciente.

\section{A visão geral de Diógenes sobre o uso da música}

Diógenes, como todo os outros estoicos e por causa do cosmopolitismo da Stoá, pensava que a música é uma prática ecumênica: “[...] uma atividade universal, uma vez que todos, gregos e os bárbaros a praticam"23. Vale observar que Diógenes reconhece aquilo que ele chama de qualidade perceptiva natural, a saber, todos os seres, portanto, reconhecem a música naturalmente e vão procurá-la em qualquer momento ${ }^{24}$. Segundo Woodward (2009), Diógenes está ciente que a música é um fenômeno que agrada a todos: "Ritmos e melodias são, de acordo com Diógenes, agradáveis a todos, e as pessoas vão procurá-las naturalmente, sem a necessidade de ser encorajadas por educação",25.

Ademais, Diógenes coloca a música ao lado de outras artes, como a ginástica e a pintura. Enquanto a ginástica exercita o movimento de forma geral, a pintura exercita os olhos. A música, pelo que podemos ver, exercita a audição, um dos sentidos mais importantes do intelecto:

Assim como a beleza e a utilidade do movimento e do descanso são demonstradas pela ginástica, a pintura, por sua vez, ensina os olhos sobre os belos objetos. Quanto a música, mesmo que pareça menos necessária do que essas outras duas [artes], na verdade sua beleza é preeminente se for apreendido pela audição (FILODEMO, De Musica, Col. 27, tradução nossa).

Poder-se-ia dizer que Diógenes, a partir dessa coluna, entende que a música é uma arte (techné) de difícil compreensão, por isso, é importante uma atenção maior ao apreciar uma melodia. Novamente, também na coluna 27, Diógenes pode ter lido Aristóxenes, é o que sugere Helen Woodward, pois, depois dessa citação, Filodemo critica Aristóxenes em outra passagem, na qual, segundo Filodemo, Aristóxenes disse

\footnotetext{
${ }^{23}$ (FILODEMO, De Musica, Col. 25, tradução nossa).

24،“[...] não só é muito útil a música para uma vida de lazer, mas também nos convém praticá-la e isso acontece, não por Zeus, mas a fim de cantar em acompanhamento de instrumentos de cordas apenas para o prazer natural" (FILODEMO, De Musica, Col. 12, tradução nossa).

${ }^{25}$ (WOODWARD, 2009, p. 57, tradução nossa).
} 
que a audição e a visão são as partes mais importantes do intelecto ${ }^{26}$. Não sabemos de fato se Diógenes cita Aristóxenes como uma autoridade nesse tema, pelo fato de o texto estar cheio de lacunas, como falamos nos parágrafos anteriores.

Filodemo, e também Woodward (2009), endossam que Diógenes não fala apenas de filosofia da música, mas ele também faz uma história da música, ou melhor, dos "usos musicais" para sustentar suas teses sobre o efeito da música no éthos. Assim, como em Plutarco no seu De Musica, Diógenes descreve o uso da música nas batalhas, como o flautista dando o tom da marcha ou a utilização do aulos nas peças teatrais.

[...] para acompanhar as atividades de guerra em público, a maioria dos gregos hoje usam a trombeta, e alguns dos mesmos nomes são tocados em privado. E para acompanhar atividades atléticas, é na trombeta também que eles soam o nome quando os corredores estão correndo em direção à linha de chegada. No pentatlo, por outro lado, é ao som dos aulos que os competidores se envolvem no salto [...] (FILODEMO, De Musica, Col. 39, tradução nossa).

Logo, parece que Diógenes quer mostrar que a música tem um poder de provocar ações ${ }^{27}$, e não só entre os guerreiros que isso acontecia. Segundo o filósofo estoico, Orfeu movimentava pessoas e objetos inanimados "com o poder de sua voz"28. Diógenes sugere, como mostram esses exemplos, que a música implica em movimento. Se a música causa ações, até em objetos inanimados, como pensa Diógenes ao citar o mito de Orfeu, isso quer dizer que a música tem um valor ético. Além do mais, de acordo com o pensamento estoico de Diógenes que mostramos nos tópicos anteriores; se a música tem um valor ético, ela também tem um valor cognitivo e pode ser passível de tratamento científico, haja vista que entre os estoicos não há separação entre ética e epistemologia.

Além disso, o uso do mito deve ser entendido aqui como uma metáfora, pois essas imagens são úteis na medida em que elas demonstram o efeito da música em uma variedade de situações ${ }^{29}$. Segundo Helen Woodward (2009), Diógenes não usa apenas exemplos míticos, como a imagem de Orfeu, para se referir ao encanto e as implicações

\footnotetext{
26“"Além disso, quando Aristóxenes disse que a visão e a audição [compõem] a parte mais importante do intelecto, além de serem mais divinos do que os outros sentidos [...]" (FILODEMO, De Musica, Col. 109, tradução nossa).

${ }^{27} \mathrm{Na}$ coluna 131, Filodemo cita uma afirmação de Diógenes a respeito do poder de uma melodia em incitar ações: "[...] a melodia tem por sua natureza o [poder] de incitar o movimento e despertar as ações" (FILODEMO, De Musica, Col. 131, tradução nossa).

${ }^{28}$ (FILODEMO, De Musica, Col. 41, tradução nossa).

${ }^{29}$ (WOODWARD, 2009, p. 67-68).
} 
éticas da música. Ele usa, também, exemplos de músicos de Creta, como Tales de Gortina $^{30}$. Tales de Gortina era um músico cretense que viajou para Esparta depois que ouviu um oráculo. Ele foi até Esparta para acabar uma praga que atingia os lacedemônios ${ }^{31}$. Outro homem importante para Diógenes é Terpandro, um músico e poeta lírico do século VII a.C., outra figura histórica usada como exemplo para mostrar o poder da música para acalmar uma agitação civil ${ }^{32}$. Esse é também outro exemplo de ex-voto, a saber, onde o oráculo ordena que o músico vá revolver um problema social ou sanitário. Ademais, Diógenes também cita o poeta Arquíloco (VII a.C.), que conta que os Carians foram acalmados por músicos na ocasião de um eclipse lunar ${ }^{33}$.

De acordo com Helen Woodward (2009. p. 72), Diógenes usa exemplos de músicos do século VII a.C., e isso parece denotar um interesse especial por um tipo de música que daquele período. Na coluna 31 Diógenes comenta algo que parece confirmar seu interesse pela música do século VII a.C.:

[...] uma instituição inicial da lei que permitia a todos praticar música enquanto proibia a introdução de inovações. Mas a disposição que floresce hoje é muito diferente. E em relação aos estilos de ditirambo, se você comparar o de Píndaro e Filoxeno, você verá uma grande diferença nos personagens que eles apresentam, embora o estilo seja 0 mesmo (FILODEMO, De Musica, Col. 31, tradução nossa).

Como mencionamos nos parágrafos anteriores, Diógenes não se refere apenas à música em palavras, mas também a música tocada separada do texto poético. Segundo Woodward (2009), isso é observável no fragmento da coluna 42, embora o texto esteja cheio de lacunas, Diógenes parece mencionar uma famosa anedota pitagórica que podemos encontrar também em Sexto Empírico:

Pitágoras, certa vez, tendo observado que os jovens em estado de frenesi báquico causado pela embriaguez de modo algum diferiam dos enlouquecidos, aconselhou o auleta que estava junto deles na folia a tocar no aulo a melodia espondaica. Depois que o auleta fez o que foi ordenado, os jovens repentinamente mudaram e se mostraram temperantes como se tivessem estado sóbrios desde o início (SEXTO EMPÍRICO, Contra os Músicos, VI, 8).

\footnotetext{
${ }^{30}$ (FILODEMO, De Musica, Col. 47).

${ }^{31}$ A história de Tales é encontrada também em outros autores, como Plutarco e Pausânias. Ver: "Descrição da Grécia” de Pausânias e "Moralia” de Plutarco.

${ }^{32}$ Filodemo se refere a Diógenes como entusiasta de Terpandro nesse comentário: "E não somos mais persuadidos, por outro lado, pela história de Terpandro que por ordem do oráculo foi convocado a pôr fím à agitação civil, mesmo que, de fato, muitos entusiastas da música concordam com o evento, e se meu adversário (ele [Diógenes] é quase sozinho neste caso) o faz cantar nas refeições comuns" (FILODEMO, De Musica, Col. 133, tradução nossa).

${ }^{33}$ (FILODEMO, De Musica, Col. 49).
} 
Diógenes parece não estar avaliando a validade história das imagens míticas, dos músicos do século VII a.C., ou mesmo da anedota de Pitágoras. O que importa para Diógenes é observar como um instrumento musical afeta a ação de uma pessoa, independentemente da letra. É considerável ressaltar novamente que uma canção não é necessariamente um problema se não expressa em uma proposição verbal. Diógenes não é um dualista como Platão, mas ele sabe que uma música instrumental pode ser entendida por uma pessoa, assim como uma canção de ninar afeta um bebê mesmo antes dele começar a falar, como explicamos nos tópicos anteriores. Portanto, Diógenes entende que a música envolve implicações éticas, tendo em vista que ela afeta um corpo em repouso $^{34}$ e também é fruto de um processo cognitivo assim como as paixões, a saber, a música não se reduz apenas ao entretenimento, mas também está no cerne de uma educação para às virtudes.

\section{Conclusão}

O que vemos ao longo deste trabalho foi um estudo das implicações éticomusicais no pensamento de Diógenes da Babilônia. Tentamos trazer uma abordagem por meio da leitura dos fragmentos de Diógenes sobre a música na obra de Filodemo de Gádara.

O caminho que trilhamos neste empreendimento passou por uma exposição do contexto histórico-filosófico que o pensador estoico se encaixava, isto é, Diógenes está inserido em uma tradição de filósofos que acredita que a música afeta o éthos. Essa tradição de pensadores que Diógenes está inserido se caracteriza também por ter sido observadora das mudanças que a música sofreu na passagem do século $\mathrm{V}$ a.C. para o século IV a.C. Deste modo, pensar o tema da ética na música foi quase um fenômeno emergente desse contexto histórico grego.

Em seguida, parte do caminho envolveu uma exposição da psicologia estoica e como a linguagem musical se encaixa nessa filosofia. A teoria das paixões estoica, diferente da filosofia platônica, não é dualista, mas monista. Ou seja: a alma é una e não dividida em partes - racional e irracional. Entender a filosofia estoica nesse caso é importante porque Diógenes pensa a música a partir dela, na medida em que a música é entendida como um fenômeno racional que provoca a alma através do assentimento

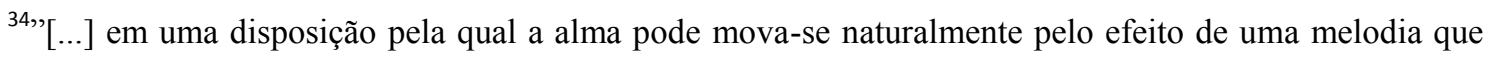
lhe convém" (FILODEMO, De Musica, Col. 36, tradução nossa).
} 
(sunkatathesis) voluntário. Embora a música possa não se configurarem uma proposição verbal, ela possui um tipo de linguagem que a condiciona ser assentida por um sujeito.

Ademais, para sofisticar a teoria estoica das paixões e caracterizar a linguagem musica, Diógenes recorre ao conceito estoico de oikeiôsis. Esse conceito vai ser de suma importância para Diógenes explicar a familiaridade natural dos seres com a harmonia musical. Esse recurso à oikeiôsis é importante para o tratamento que Diógenes dará a música, porque a filosofia estoica é, grosso modo, naturalista. Portanto, a partir desse conceito de oikeiôsis Diógenes da Babilônia explica o carácter virtuoso da música por meio da assimilação natural.

E, por fim, esclarecemos a visão geral que Diógenes tem da música. Explicamos os relatos míticos, históricos e anedóticos que Diógenes se utilizará para sustentar a sua tese de que a música provoca movimento de um corpo em repouso, sendo assim, pode afetar o éthos. Enfim, Diógenes, diferente do epicurista Filodemo, foi um filósofo preocupado em fornecer à música um tratamento científico, na medida em que ele busca de todas as maneiras demonstrar por meio desses exemplos o efeito da música em nossos juízos éticos e morais.

\section{Referências:}

DIOGENES L. Vidas e Doutrinas dos Filósofos Ilustres. Trad: Mário da Gama Kury. Brasília: Editora UnB, 2014.

DINUCCI, A. A Relação entre virtudes e vícios e paixões boas e más no estoicismo. Prometheus - Journal of Philosophy, 11(30), 2019.

DELATTRE, D. Philodème de Gadara: Sur la musique. 2 vols. Paris: Les Belles Lettres, 2007.

FUBINI, E. La estética musical desde la Antigüedad hasta el siglo XX. Alianza Editorial, 2005.

GOURINAT \& BARNES, Jean-Baptiste \& Jonathan, D. Ler os estoicos. Trad. Paula S.R.C. Silva.São Paulo: Edições Loyola, 2013.

LONG, A. A. Stoic Studies. Cambridge, 1996. 
NUSSBAUM, M. Upheavals of Thought. The Intelligence of the Emotions. New York, 2001.

PLATÃO. A República. Tradução: Edson Bini. Editora Edipro, 2012.

PLUTARCO. Sobre a Música. In: SOARES, C., ROCHA, R. Plutarco Obras Morais: Sobre o afecto aos filhos, Sobre a Música. Tradução de Roosevelt Rocha. Coimbra: Centro de Estudos Clássicos e Humanísticos, 2010.

PHILODEMUS. De musica liberorum quae exstant. Editora: Nabu Press, 2010.

ROEDER, S. O Contra os Músicos de Sexto Empírico: Introdução, tradução e comentários. Dissertação de mestrado, UFPR, 2014.

TOMÁS, Lia. Vozes dissonantes: precursores da autonomia da música na Antiguidade. in: DUARTE, R., SAFATLE. V (Orgs.). Ensaios sobre Música e Filosofia. São Paulo: Humanitas, pp. 147-155, 2007.

GRACYK, and KANIA, Theodore e Andrew (eds). The Routledge Companion to Philosophy and Music. London and New York: Routledge, 2011.

WOODWARD, L. H. Diogenes of Babylon: A Stoic on Music and Ethics. Dissertação (Master of Philosophy in Classics) - UCL, 2009. 